\title{
Safeguarding Intangible Cultural Heritage: The Amazonian Kichwa People
}

\author{
Claudia Patricia Maldonado-Erazo ${ }^{1,2}$, Nancy P. Tierra-Tierra ${ }^{1}$, , María de la Cruz del Río-Rama ${ }^{3, *(D)}$ \\ and José Álvarez-García 4 (D)
}

1 Facultad de Recursos Naturales, Escuela de Ecoturismo de la Superior Politécnica de Chimborazo-ESPOCH, Riobamba 060155, Ecuador; claudia.maldonado@espoch.edu.ec (C.P.M.-E.); nancy.tierra@espoch.edu.ec (N.P.T.-T.)

2 Programa de Doctorado en Desarrollo Territorial Sostenible (R015), Instituto Universitario de Investigación para el Desarrollo Territorial Sostenible (INTERRA), Universidad de Extremadura, 06006 Badajoz, Spain

3 Business Management and Marketing Department, Faculty of Business Sciences and Tourism, University of Vigo, 32004 Ourense, Spain

4 Departamento de Economía Financiera y Contabilidad, Instituto Universitario de Investigación para el Desarrollo Territorial Sostenible (INTERRA), Facultad de Empresa Finanzas y Turismo,

Universidad de Extremadura, 10071 Cáceres, Spain; pepealvarez@unex.es

* Correspondence: delrio@uvigo.es

check for updates

Citation: Maldonado-Erazo, C.P.; Tierra-Tierra, N.P.; del Río-Rama, M.d.l.C.; Álvarez-García, J. Safeguarding Intangible Cultural Heritage: The Amazonian Kichwa People. Land 2021, 10, 1395. https:// doi.org/10.3390/land10121395

Academic Editor: Hannes Palang

Received: 5 December 2021

Accepted: 8 December 2021

Published: 17 December 2021

Publisher's Note: MDPI stays neutral with regard to jurisdictional claims in published maps and institutional affiliations.

Copyright: (c) 2021 by the authors. Licensee MDPI, Basel, Switzerland. This article is an open access article distributed under the terms and conditions of the Creative Commons Attribution (CC BY) license (https:// creativecommons.org/licenses/by/ $4.0 /)$.

\begin{abstract}
Indigenous communities express their concern about the weakening and low appreciation of their millenary and ancestral manifestations and knowledge, due to society's accelerated globalization. This fact has caused intergenerational transmission to be minimal, resulting in a gradual cultural erosion and loss of collective memory of human groups. The purpose of this study is to safeguard of the Intangible Cultural Heritage ( $\mathrm{ICH})$ of the Amazonian Kichwa nationality through identification and records of cultural manifestations. The analysis corresponds to a descriptive process of all the information collected, which was built from the development of multiple processes of cultural revitalization that correspond to in-depth interviews with community leaders and participatory workshops with all members of the community. During the process, an increase in the exchange of knowledge was observed, in addition to constant cultural insurgency in which the peoples maintain themselves in order to safeguard their cultures.
\end{abstract}

Keywords: indigenous communities; Amazonian Kichwa nationality; Amazonia; intangible cultural heritage

\section{Introduction}

The current society characterized by both economic, political, social and cultural globalization leads to the homogenization of cultural ones, producing the phenomenon of absorption of minority cultures by majority cultures, which represents a threat to cultural diversity [1] (p. 28). "Cultural heritage is understood today as a social and symbolic construction generated from and for the present and constitutes not only a socio-economic resource of attraction for tourism and the cultural industry but, fundamentally, a resource of political claim and identification of native peoples" [2] (p. 1). This includes the works of its artists, architects, musicians, writers and scholars, as well as the anonymous creations, arising from the popular soul, and the set of values that give meaning to life, that is, the material and non-material works that express the creativity of that town; language, rites, beliefs, historical places and monuments, literature, works of art, and archives and libraries [3].

Indigenous peoples are the holders of a great diversity of tangible and intangible cultural heritage (uses, representations, expressions, knowledge and techniques), also known as living heritage. The United Nations Educational, Scientific and Cultural Organization [4] defines indigenous cultural heritage "as the cultural heritage of the past of a community, 
with which it currently lives, and which transmits to present and future generations, and which is constantly recreated by them based on their environment, their interaction with nature and their history, infusing them with a feeling of identity and continuity, thus helping to promote respect for cultural diversity and human creativity. At the same time, they constitute the uses, representations, expressions, knowledge and techniques together with their material manifestations: instruments, objects, artefacts and socio-cultural spaces that are inherently recognized as integral parts of their cultural heritage.".

In the specific case of Ecuador, the birthplace of the Kichwa people, a country that has signed the Convention for the Safeguarding of the Intangible Cultural Heritage [4], this considers the five general categories included in the document, called areas of Intangible Cultural Heritage, which are:

(1) traditions and oral expressions: "Set of knowledge and knowledge expressed in myths, legends, stories, prayers, literary expressions, as well as narratives of local memory and others that have a symbolic value for the community and that are transmitted orally from generation after generation" [5] (p. 24).

(2) performing arts: "Category referring to representations of dance, music, theater, games and other expressions linked to ritual or daily, public and private spaces that have a symbolic value for the community and that are transmitted from generation to generation." [5] (p. 26).

(3) social uses, rituals and festive acts: "Set of cultural practices, manifestations and representations developed in a spatial and temporal context, such as religious and profane celebrations. They are rituality's associated with the life cycle of groups and individuals that are transmitted from generation to generation in order to promote the social cohesion of the groups." [5] (p. 28).

(4) knowledge and uses related to nature and the universe: "Set of knowledge, techniques and practices that communities develop and maintain in interaction with their natural environment and that are linked to their belief system regarding gastronomy, traditional medicine, symbolic spaces, productive techniques and ecological wisdom, among others. They are transmitted from generation to generation and have a symbolic value for the community." [5] (p. 29).

(5) traditional craft techniques: "They are a set of activities of an essentially manual nature that include the instruments for their elaboration. This area is the most tangible of intangible heritage; however, it is interesting to highlight the knowledge and know-how that is transmitted from generation to generation, rather than the objects or products of the artisanal activity." [5] (p. 30).

All this heritage must follow a safeguarding process recognized in the Convention for the Safeguarding of the Intangible Cultural Heritage [4], so that the countries that ratify the agreement assume the obligation to safeguard the intangible cultural heritage of their territory. Understanding this "as a methodological process that includes the identification (registration), research (diagnosis) and the definition of specific actions to achieve the continuity of the manifestations of the Intangible Cultural Heritage (safeguard plan)" [5] (p. 35). This process is supported by the binding multilateral instrument for the safeguarding of the intangible cultural heritage of the 2003 Convention [4]. This instrument is configured by four main objectives: (1) safeguard the intangible cultural heritage; (2) guarantee respect for the intangible heritage of affected communities, groups and individuals; (3) raising awareness at the local, national and international levels of the importance of intangible cultural heritage and of its reciprocal recognition; (4) foresee international collaboration and aid [4].

At present, indigenous communities, together with a set of specialized organizations created to safeguard intangible heritage and ensure its transmission to future generations, express their concern about the loss and lack of appreciation of living heritage. Intangible heritage, according to the United Nations Educational, Scientific and Cultural Organization [6] (p. 2) "is important because it offers communities and individuals a sense of identity and continuity. It can promote social cohesion, respect for cultural diversity and 
human creativity, as well as help communities and individuals connect with each other." Thus, culture has now become a fundamental pillar of the United Nations Declaration on the Rights of Indigenous Peoples [7].

In this context, the objective is to safeguard of the Intangible Cultural Heritage (ICH) of the Amazonian Kichwa nationality based on the identification and registration of cultural manifestations. In a first phase, the data obtained was investigated and processed, and in a second phase, promotional and dissemination materials were prepared, including this document.

"Inventories are integral to the safeguarding of intangible cultural heritage because they can raise awareness about intangible cultural heritage and its importance for individual and collective identities." [8]. According to UNESCO [4], "The process of inventorying intangible cultural heritage and making those inventories accessible to the public can also encourage creativity and self-respect in the communities and individuals where expressions and practices of intangible cultural heritage originate. Inventories can also provide a basis for formulating concrete plans to safeguard the intangible cultural heritage concerned (... )" [8]. It should be remembered that safeguard measures should always be designed and applied with the consent and participation of the community.

The novelty lies in the fact that it is the first study carried out in this context, and with which it is intended to follow the guidelines of UNESCO; "Safeguarding living heritage is fundamental for indigenous peoples because their heritage is the basis of their identity, of their cultures, and the continuous transmission of this heritage is what will strengthen the identities and cultures of the peoples" [5] (p. 3), as well as, the understanding of the intangible cultural heritage of the different communities contributes to intercultural dialogue and fosters mutual respect for other forms of life [4].

The document is divided into four sections. In the introduction the subject under study is contextualized and the objective is stated. The second section contextualizes the Amazonian Kichwa nationality and the third section Identification of the Intangible Cultural Heritage (ICH). To finalize, the fourth section presents the conclusions.

\section{Contextualization of the Amazonian Kichwa Nationality}

\subsection{Self-Definition}

They call themselves Runas which means "man" or "person". This nationality is settled in a large part of the Ecuadorian Amazon, mainly in the provinces of Sucumbíos, Napo, Orellana and Pastaza [9]. They are the result of continuous and intense interethnic relations, which is a condition that allows for internal differentiation. According to Vizcaíno [10], the Napo Kichwas have two opposing identity concepts: Ali Runa or the good Christian Indian, and Sacha Runa, or the forest inhabitant. Meanwhile, the Pastaza Kichwas define themselves as Runas, who mark their ascription and belonging to the same intra-ethnic identity space as opposed to other non-Kichwa indigenous peoples.

\subsection{Nationality Spatiality}

This nationality is organized into two groups: "Napo runa" or Napo Kichwas and "Canelos" or Pastaza Kichwas. According to Restrepo \& Cabrejas [11], the Amazonian Kichwas originate from an ethnic fusion, due to the fact that diverse ethnic groups were able to converge to the missionary centre of the Amazon region, escaping from the oppressions experienced by control regimes, which is why they were 'kichwized' by missionaries, from the 16th century [12]. The initial societies were Saparas, Western Tukanos and Quijos, from which two distinct cultural groups emerged, Canelos Kichwas and Quijos Kichwas [9].

The Napo Kichwas settled in the cantons of Tena, Archidona, Quijos and Carlos Julio Arosemana Tola [13], that is, along the banks of the Napo, Aguarico, San Miguel and Putumayo Rivers; they are also found in the urban areas of the province of Sucumbíos, as well as in neighbouring areas of Colombia and Peru [14]. 
Meanwhile, the Pastaza Kichwas are located in the four cantons of the province, Pastaza, Arajuno, Mera and Santa Clara [15], along the banks of the Arajuno, Curaray, Bobonaza, Pindo, Anzu and Puyo Rivers [16] (Table 1 and Figure 1).

Table 1. Geographical location of the Kichwas.

\begin{tabular}{lll}
\hline Province & Canton & Parishes \\
\hline Napo & Tena & $\begin{array}{l}\text { Tena, Ahuano, Carlos Julio Arosemena Tola, Chontapunta, Pano, Puerto } \\
\text { Misahuallí, Puerto Napo y Tálag } \\
\text { Cotundo y San Pablo de Ushpayacu }\end{array}$ \\
& Archidona & $\begin{array}{l}\text { Papallacta } \\
\text { Quijos }\end{array}$ \\
& Carlos Julio Arosemana Tola & Carlos Julio Arosemana Tola \\
\hline Pastaza & Pastaza & $\begin{array}{l}\text { Puyo, Canelos, 10 de agosto, Fátima, Montalvo, Río Corrientes, Sarayaku, } \\
\text { Tarqui, Tnte. Hugo Ortiz y Veracruz } \\
\end{array}$ \\
& Arajuno & Arajuno y Curaray \\
& Mera & Mera y Madre Tierra \\
& Santa Clara & Santa Clara \\
\hline
\end{tabular}

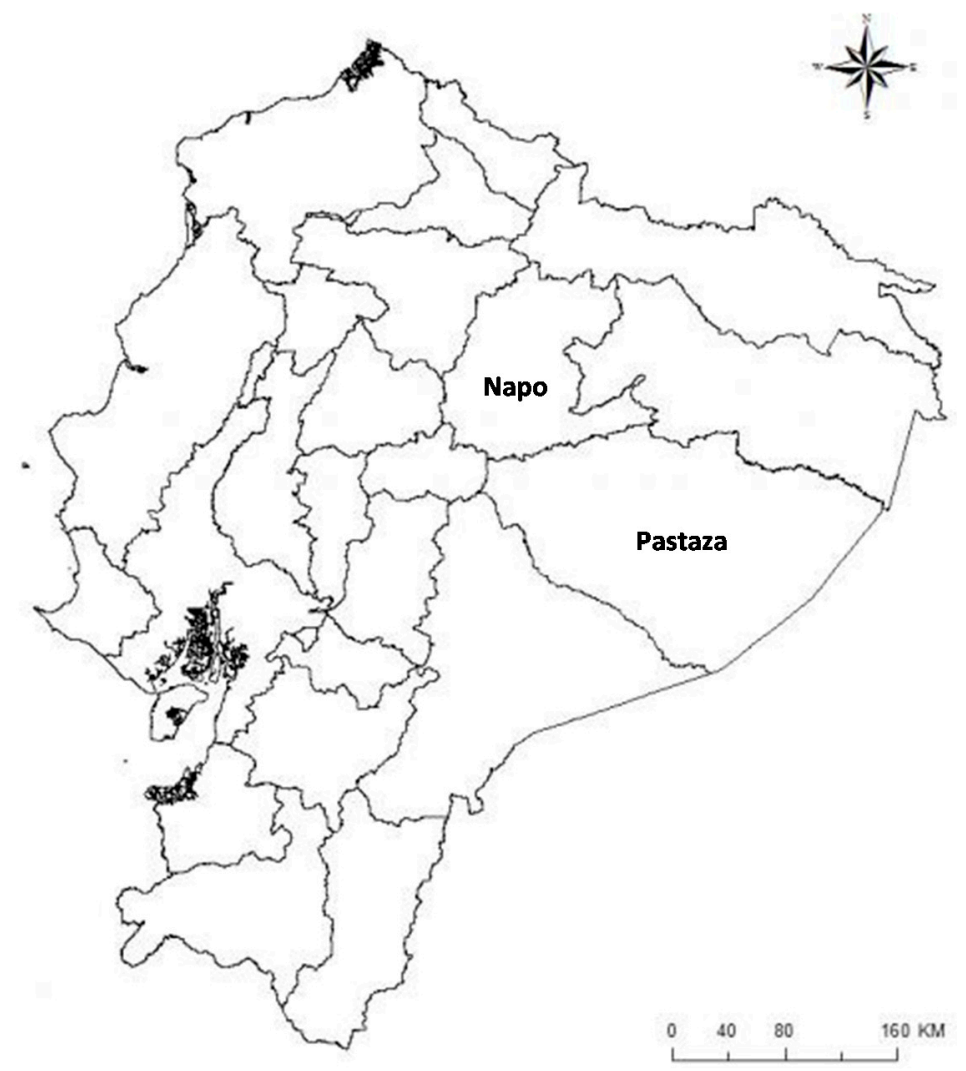

Figure 1. Ecuador Political Map.

\subsection{Temporality}

The well-known region and subsequent Governership of Quijos is established as a strategic point to enter the Amazonian area of Ecuador, due to the fact that it was located in the mountain ridge, that is, in the eastern foothills of the Andes Mountains towards the Amazon [17]. Although it has not been possible to delimit precisely the territories that comprised the province or region of the Quijos [18], some authors have concluded that the region included the valleys of the Cosanga, Papallacta, Quijos, Coca, Suno and Misahuallí Rivers, extending up to the upper courses of the Napo and Aguarico Rivers [19-21].

This point was established as the gateway to the Amazon colonization process [18]. From 1537-1557 the first colonial incursions took place, which allowed for the exploitation 
of gold and silver mines, as well as the extraction of cinnamon, a highly regarded spice for the Spanish. It also provided access to several expeditions that longed to find "El Dorado" [19]. This first period was characterized by brutal confrontations between the indigenous population and the Spaniards, which led to a reduction in the indigenous population density, breakdown of the reciprocity system between the mountains and the Amazon [17], in addition to constant looting of goods (resources of the the region) [16]. According to Hortegón et al. [19], "no Spanish city was founded, no "encomiendas" were distributed in Quijos, no reservations were made, and no doctrines were created" (p. 15).

In these early years, two expeditions of great importance stand out: the first one, commissioned by Francisco Pizarro to Gonzalo Díaz de Pineda, which began in December 1538 and culminated in February 1539, advanced as far as the Sumaco volcano [21]. The second one took place in 1541, under Pizarro's command, guided by Díaz de Pineda and later joined by Francisco de Orellana, during which confrontations with the Quijos took place and they advanced as far as the River Payamino, an area of the Omaguas and where the "Country of Cinammon" was believed to be [22]. After the accidental separation from Orellana on 26th December, 1541, which ended in the discovery of the Amazon River, the expedition returned to Quito in 1542 without resources, because they found neither gold nor silver and very little cinnamon, thus debunking the myth of "El Dorado" [19,22], and for approximately seventeen years, no new conquest ventures were undertaken (1542-1559). In addition to the previous dissatisfaction, the difficult terrain that prevented easy access, and the presence of extremely aggressive groups discouraged the colony from advancing in this region [17-19,21].

Then from 1557 to 1576, the colony was strengthened or consolidated in the Amazon, although it did not occur as strongly as in the sierra region. In 1559, Gil Ramírez Dávalos entered the area with the help of the cacique Don Sancho Hacho de Velasco, who eased the subjugation due to his knowledge of the local languages. Thanks to this collaboration, the city of "Baeza de la Nueva Andalucia" was founded, which was the first Spanish settlement [22] (p. 89-95). After this, the cities of Ávila, Archidona and San Juan de los Dos Rios de Tena were founded in the region, which, as Muratorio [23] points out, initiated the process of socio-historical production of the colonial territory in what was called La Gobernación de Los Quijos, Sumaco y la Canela, which Rodrigo Núñez de Bonilla was responsible for [19].

During this administration, there was an increase in the use of the indigenous population for construction, crops and mining, which was a condition that began to break relations and was aggravated by the constant trips of the indigenous people to Quito to supply the colonial settlement with food and provisions, which led to the first indigenous uprisings [21]. By 1561, the third governer was proclaimed, Melchor Vásquez de Ávila -who administered the territory from Cuzco all the time-, through his provisions the subjugation of the "rebellious Indians" was completed, establishing the colony in the area. In 1568 , indigenous "doctrines" and "reservations" were developed as systems for regrouping Indians into larger settlements, which facilitated evangelization and population control (native control and hunting packs were eliminated) [18], while at the same time liberating space for colonial rule and dismantling the indigenous social organization [17,24]. The doctrines were mainly handed over to the Dominican friars [18]. According to Padilla [25], tributes were imposed on the indigenous people for having been born in America, but these taxes were increased because the value of the fines for mistreatment of the "encomenderos" was transferred to the indigenous people, which were elements that increased indigenous exploitation and provoked strong uprisings in the future [21].

From 1576 to 1600 , there was a period marked by indigenous uprisings and the decline of the colony. As Rumazo [22] details, the uprising of 1578 is established as the most important, since it attempted an integration of regions, given that the mountain chiefs (caciques serranos) agreed to carry out the uprising at the same time and the leadership fell to the pendes. The cities of Archidona and Ávila were devastated, although during the attack on Baeza, the uprising was harshly repressed by Rodrigo Núñez de Bonilla, which discouraged further confrontations [18]. 
Gradually, Spanish presence decreased due to the scarcity of large-scale mines and gold-panning sites, the reduction of the indigenous population and the low production of cinnamon, which made the region unprofitable [17].

The transition from the colonial to the republican era did not represent a change in the situation of the region, but instead, the control and domination systems already indicated continued. From 1660 to 1661, a segmentation of the doctrines can be seen: the Jesuits entered to take charge of Archidona (towns of Tena and Puerto Napo), the Dominicans continued in Baeza and a priest in Ávila. This new scenario was to have a decisive influence on the process of conlonization, acculturation and relationship with the indigenous people.

In relation to the language, in order to facilitate the evangelization process, the missionaries preferred to learn only one language, an action whereby they encouraged the use of Kichwa [26], for example, in Archidona the Jesuits started a school for interpreters with foreign natives (coming from other regions or not necessarily Kichwa-speaking). According to Garcés [27], this was all with the purpose of encouraging the use of Kichwa among the population. This and other actions consolidate the thesis that the Kichwa language was used as a commercial language, which is supported by Magnoni [28] and Whitten [29], who state that several languages used by the society that settled in what today comprises the inter-Andean alley and the Amazon region, were eliminated in order to maintain exchange and trade relations. This is supported by the political impositions used by the Incas, who established Kichwa as the lingua franca of the entire Sierra. Although the pre-Inca languages did not disappear, the unification process of the language, imposed by the Incas in the 15th century [26] was facilitated.

Then, in relation to its population density, there is evidence of other historical facts that correspond to the emergence of measles outbreaks during the years 1660 and 1665, of chickenpox waves in 1756 and 1762, in addition to a number of indigenous revolts and capture of the population as slaves by Portuguese expeditions in 1762, which caused a reduction of approximately $80 \%$ of the population participating in the missions [26].

All these events caused the population to retreat towards the interior of the rainforest, which did not prevent "white people's diseases" from disappearing, but instead, spread deeper into the forest [30]. In addition to this, this led to the termination of all evangelization processes, mainly due to the low presence of the indigenous population, as indicated by the records of the Quijos and Macas Governorship. This was followed by the expulsion of the Jesuits in 1767 by order of the Spanish King [17], resulting in the departure of the parish priests of Archidona and Puerto Napo, who were subsequently replaced by clergymen, characterized by abuse in the collection of tithes for their services [21].

Then, in 1844, the exploitation of rubber, an endemic product of American rainforests, began on a larger scale, turning the region into an area of interest. The arrival of English expeditions to Brazilian and Peruvian forest areas is observed, in order to obtain this desirable material. To do so, they took advantage of indigenous knowledge to identify the plants and enter the forest, generating a social battle that caused the genocide of indigenous populations due to the abusive work and torture processes to which they were subjected [31]. In addition, the relocation of some Napo Runa populations for extraction processes in the middle basin of the Putumayo River and the San Miguel and Aguarico Rivers was observed, according to the analysis of indigenous records carried out by Mongua-Calderón [32].

After that, at the continent level, there were several social changes, resulting from the independence struggles generated in various latitudes, processes in which the Quijos had an incipient participation [21]. Although the political-administrative structures were modified throughout the region, the reality of these territories remained, the relations of labour exploitation and abuse in the collection of taxes continued.

Once the Republic of Ecuador was established, in 1869, the Jesuit mission returned to Alto Napo in the Oriente province, which was created from the First Law on Territorial Division of 1861 [33]. This action was carried out by President García Moreno, since this province was controlled from the capital of Quito because it did not have a significant 
population centre. This mission had a regional approach, from which schools were created. Six years later, García Moreno was assassinated, which caused a decrease in Jesuit influence and thus, relations were aggravated, causing constant uprisings that were put down. With the transition to a secular government system led by Eloy Alfaro, they left the region in 1896.

For several years the region was abandoned, but the administrative division of the Oriente province was reconfigured, which in 1920 was divided into two provinces: to the north the Napo-Pastaza province, whose capital was Tena, and to the south the SantiagoZamora province with Macas as its capital. In 1922, the Josephine Missionary Order was established, starting in the city of Tena and extending to Loreto, Napo-Pastaza province [31]. Its work focused on education and health, through the provision of infrastructure for this purpose, mainly within the areas that today constitute the provinces of Napo and Orellana. It was an action that caused the displacement of girls, boys and adolescents, exacerbated by the boarding systems that were implemented to ensure assistance, thus distancing the population from populated centres [34].

As Albán [18] states, the human groups known up to this point as Quijos undergo a total displacement of their languages and completely adopt Kichwa, a result of indigenous miscegenation processes, giving rise to new ethnic identities such as Napo Kichwa or Napo Runas, Curaray Kichwa (Canelos) and Sucumbíos Kichwa.

The aforementioned rubber boom lasted until 1941 due to international needs. However, in that year, the national reality due to the conflict with Peru paralyzed the flow of river trade, causing the implementation of agricultural haciendas that retained the workforce with various activities to continue financing rubber, generating an uncontrolled peonage system based on indebtedness, migration towards other areas and thus, family separation [35].

After that, the territorial division was modified again in the 1950s, when the provinces were divided into Morona Santiago and Zamora Chinchipe, and then into the provinces of Pastaza and Napo, which would later be subdivided into two more provinces: Sucumbíos and Orellana [36].

During the 1960s, a new social change took place based on the internal colonization process (occupation generated mainly by Lojanos and Manabis) within the Amazonian territory, which was encouraged by the1964 Agrarian Reform Law or the 1964 Law of Vacant Land, as well as the 1978 Colonization Law [37]. This process generated more problems than solutions for the country. On the one hand, it caused an accelerated population growth, which in the case of the Napo province was $7.5 \%$ per year, being the highest in the country and which resulted in the need to allocate more resources to the management of this area $[18,37]$.

Human migration was also encouraged in order to take advantage of the land for agriculture, which did not work because of the low fertility of this territory and led to the overexploitation of the few agricultural lands, causing an expansion of the agricultural frontier in relation to the primary Amazonian forest. These elements led to a drastic reduction in the areas available for hunting, fishing, harvest and subsistence agriculture by indigenous families, including the Kichwas.

These practices, in contrast to those introduced by internal colonization, are characterized by the non-affectation of space and respect for the natural cycles of ecosystems. Consequently, changes in access to resources led to a change in the patterns of production, settlement and social organization [38], motivating the generation of organizational structures for the representation and struggle for rights that have been maintained to this day and have worked for the consolidation of Ecuador as a plurinational country.

\subsection{Social, Political and Economic Organization of the Nationality}

The Amazonian Kichwas have ancestrally organized themselves into two types of families: the ayllu, which corresponds to the nuclear family, and the muntun, which is an extended family figure [21]. The ayllus establish their origin from the head of the 
family or the most prestigious person in the family group [21], whereas the muntun were the grouping of several nuclear families, which controlled territorial spaces, where their centres of production and reference were established. Nowadays, the ayllu is the maximum unit of territorial settlement and their union generates communities, associations, centres and cooperatives.

Families are formed mainly through marriage, by means of exogamous or endogamous alliances, since relationships are allowed between members of the same community, as well as with people of other nationalities. It is necessary to mention at this point, that bilateral marriage between cross-cousins is allowed. In any form of family constitution, only one spouse is allowed, so they are monogamous.

Kinship relationships have shifted from a totemic (sacred animals) descent relationship to one based on the family surname, whereby the kinship system is bilateral, as a person will belong to both the father's and mother's family group.

Within the marriage rules, it is mentioned that women can get married from the age of 15-16, whereas men can get married between the ages of 18-20, since their parents must ensure that they are able to provide the necessary resources for the family that is about to be constituted [9]. Wedding rings are given voluntarily after the marriage proposal. The residence of the married couple is patrilocal, which means that once the marriage has taken place, the wife moves to live with her husband's parents, to become one more member of the nuclear family.

Ritual kinship works in two ways: within the family in which a member is designated to perform the first haircut, the first cargada (first person to hold the baby in her arms after its mother), among others; and outside the family in which inter-ethnic relationships can be established through godparenthood or "compadrazgo" for ritual acts such as baptisms or marriages.

Regarding the socio-political organization, the social space is organized in the llackta, in which the runakuna (people), ayllukuna (families) and apukuna (authorities) converge. Within this space, the activities to be carried out by all the members are organized and planned, in relation to the natural and cultural resources shared in the social space.

The authorities are made up of the kuragakuna and yachakkuna. The kuraga are responsible for the administration of order and justice based on the customary and formal law of the people and whose function falls mainly on the Yachak [9].

On the other hand, in some communities much closer to the urban areas of the territory, the organizational systems were modified to cabildo structures, i.e., election processes are carried out, in which the highest authority, which is the general assembly (all members of the community) elect a board per year. This cabilido is made up of: a president, vice president, secretary, treasurer and trustee.

In order to work for the defence of the collective and legitimate rights of communities, they organized themselves into structures of different levels (Figure 2). Finally, the traditional economic organization is based on itinerant slash-and-burn agriculture in the purinas (treks), in addition to the chacra or forest plantations. These areas are subject to rituals or cultural practices for their care, which are strictly respected as they form part of the cosmovision. As a complement, hunting, fishing, harvest, and the exchange of products and handicrafts are also practised.

In relation to hunting, this practice is regulated on the one hand by formal law, but it is also subject to the cosmovision of the Sacha Runa (forest man) who, based on his knowledge of the restrictions and rituals, guarantees that good specimens are obtained.

It is necessary to mention that, the transmission of knowledge begins from a very young age when making small traps such as: tuklya used to catch small birds, the tikta that enables to hunt medium-sized animals such as rabbits, agoutis, snakes, among others. The young people, on the other hand, make traps with a carbine for slightly larger animals and accompany them, which enables them to strengthen their practices through observation. They are also responsible for carrying the elements necessary to make the parents' food (sacha runas); the youngsters are obliged to have the food ready for the hunters, otherwise 
they are punished with chili pepper (Capsicum annuum), which is a nettle, that is spread over the body in the form of a whip and with a bath in cold water at dawn so that they learn not to be lazy.

\section{Third Level}

- Confederación de Nacionalidades Indígenas del Ecuador (CONAIE)

- Confederación de Nacionalidades Indígenas de la Amazonía Ecuatoriana (CONFENIAE)

\section{Second Level}

- Organización de Pueblos Indígenas de Pastaza (OPIP)

- Federación de Organizaciones de la Nacionalidad Kichwa de Sucumbíos del Ecuador (FONAKISE)

- Federación de Comunas de Nativos de la Amazonía Ecuatoriana (FCUNAE Orellana)

- Federación de Organizaciones de la Nacionalidad Kichwa del Napo (FONAKIN)

\section{First Level}

- General Assembly

- Council

- Ayllukuna

Figure 2. Political organization by levels.

They usually hunt the following animals: woolly monkey, capuchin and spider, agouti (rodent of the genus Dasyprocta), capybara (rodent of the family of the cavids), squirrel, anteater, armadillo, river otter, peccary, deer; among the birds: toucans, macaws, aracari (toucans of the genus Pteroglosus), quail, among others.

It can also be seen that due to the integration processes of the communities into the market economy, they have seen the need to incorporate economic activities such as monoculture agriculture. The main products are bananas, cassava, corn, naranjilla, palm heart, cotton, coffee and cocoa; which are used for self-consumption and for sale in the local and provincial market; about $75 \%$ of the population declares this as their main income. The activities of cattle raising and tourism have also been incorporated, which are causing alterations both in the ecosystem and in the contents of its culture. They are involved in raising cattle, horses and to a lesser extent, domestic animals: chickens, ducks and turkeys, which are aimed at self-consumption and also at the provincial market. Handicrafts are established as a lower production activity, which is aimed at self-consumption and local markets, and is also in demand in the tourist market.

\subsection{Space-Time Organization}

The entire space of the Amazonian Kichwas is organized and understood from three worlds: Awa Pacha, Kay Pacha, and Uku Pacha and each dimension has its explanation and protectors or caretakers (Figure 3).

Awa Pacha: first level or upper space-time in which time passes slowly. It corresponds to the abode of the stars in which the sun, the moon (killa) and the stars (between the ancient Kuyllur and Dužiru) dwell, as well as being the city of the supreme, being Pachakamak, who gives wisdom and controls the Yachaks.

Kay Pacha: second level or space-time of this world in which time passes a bit faster than in Uku Pacha. Here the human being develops his behaviour and relationships, on 
the one hand, with other beings such as animals, plants, natural resources, abiotic elements; while, on the other hand, social relations are also developed between members of the same human group or intercultural ones with different peoples or nationalities. It should be noted that, here we also find the space-time of the dead, the souls (aya) circulate with the living beings, they are rarely visible, but they share their knowledge with the living.

Uku Pacha: last level and space-time in which the spirit-men called supay or ungui live. They are short and feed on smells that is why they do not make bowel movements [39]. These spirits may temporarily visit the Kay Pacha and appear to people with connecting gifts. In the opposite direction, people can go from Kay Pacha to Uku Pacha through the ingestion of ayahuasca, but always with the guidance of a Yachak.

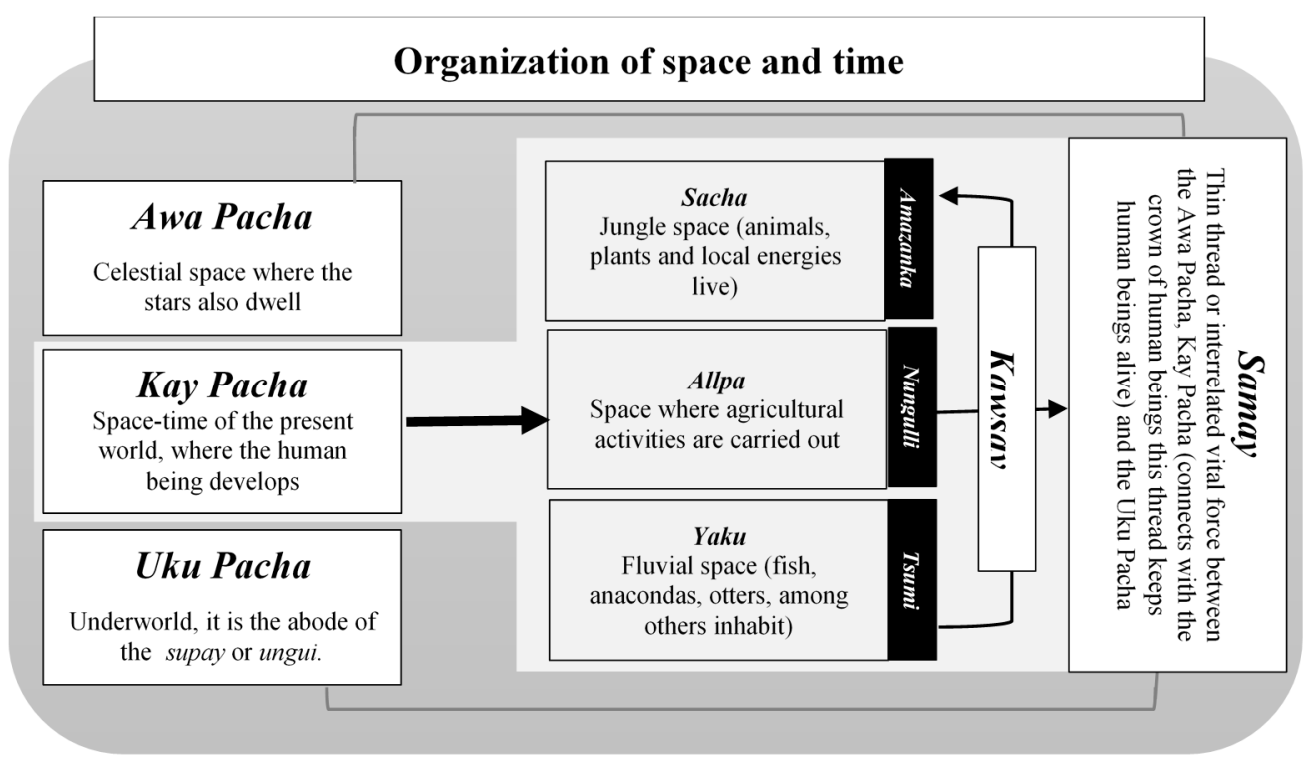

Figure 3. Organization of space and time. Source: Calapucha [40] (p. 226).

The Uku Pacha is similar to a city, in which there are social organization structures (authorities for society and religion), as well as infrastructures for the development of life (houses, streets, transport, etc.), which can also be called Kuri Pacha, since gold is plentiful and everything is made of this material. Gold also communicates with the supay.

The supay are considered local spirits or creatures of nature that live in the forest. They are beings that live in their own space-time, but when they see threats to their world they defend themselves. They are neither negative nor evil forces or demons, as Western religion considers them to be.

There are two smaller spaces called Puyu Pacha and Nina Pacha (Figure 4). The former corresponds to a celestial space-time, where the youngest stars and the ray dwell, as well as celestial families that follow the ray's orders. The latter corresponds to the last space-time which houses the fire, which is only accessible after death. All time-spaces intertwine with each other, through a force they know as Samay.

\subsection{Reciprocity Practices}

The social dynamics of the communities is regulated by reciprocity and redistribution, which is why there is an exchange of goods and services within the allyus and the communities. Community work is regulated by means of symbolic payment for equal work called randi randi, which can be given in two ways. Individual such as the Makimañachi or lending a hand, which consists of a mutual collaboration, when a member of the community needs to carry out some work or activity on their land, they ask for the help of the other members and this will be repaid when another community member requires it. Collective as the Minka or minga, which regulates intra and inter-community collective work and corresponds to an activity or work such as road or path maintenance for the good of the 
community, in which all the families (men, women, young people and adults) of the sector or community where it is carried out participate.

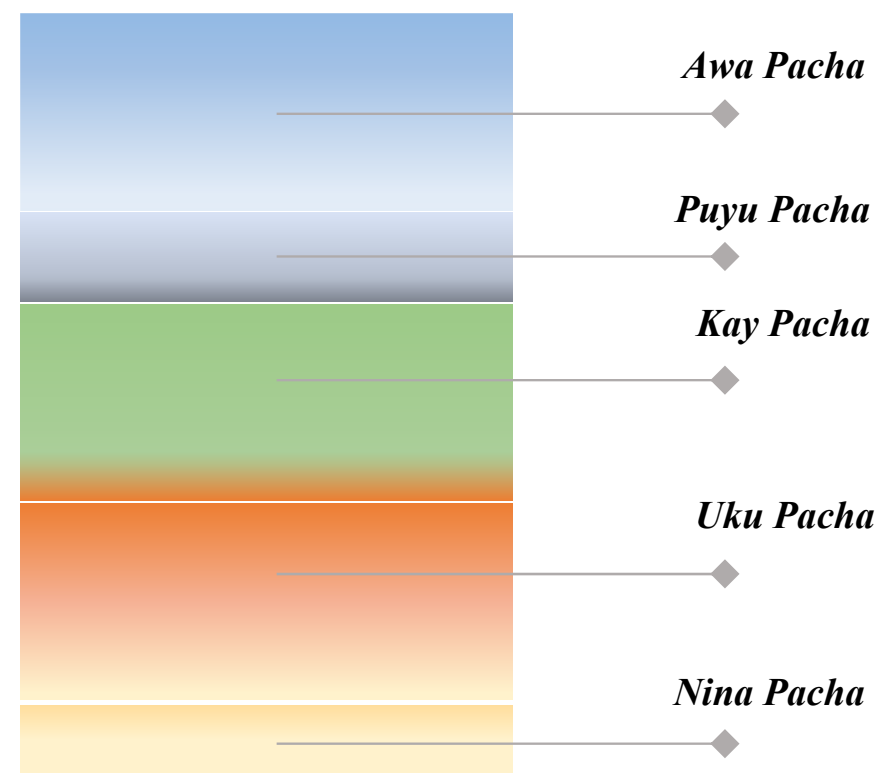

Figure 4. Organization of all time-spaces. Source: Calapucha [34] (p. 226).

\section{Identification of the Intangible Cultural Heritage (ICH)}

\subsection{Methods and Materials}

The research is based on a participatory methodology that allows for the cultural revitalization process, focusing on strengthening and enriching the culture of a village or community. In this way, through dialogue between the members of the community, the identification and recovery of the manifestations and representations that form part of their culture is initiated. This process leads to enriching general knowledge by actively involving all members, which in this case are the five participating communities of the parish of Puerto Napo, Napo province.

The information collection process began by developing participatory community workshops in which different community stakeholders (boys, girls, youth, women, adults, the elderly, and community leaders) interacted. Authorization was obtained through free, prior and informed consent, in order to collect all the information required for developing the work. Furthermore, it complies with the provisions of the ILO Convention No. 169 [41] and the Nagoya Protocol [42], as well as the provisions of Article 530 of the Ecuadorian Code of Ingenuity [43].

During the participatory workshops, an ethnographic record was made of the highest number of cultural manifestations of the Amazonian Kichwa Nationality. It is necessary to mention that, within the five communities under study, only $82.86 \%$ of the total population was self-identified as indigenous. Subsequently, the data of the registered cultural manifestations was complemented with information previously obtained in other research, with the purpose of verifying, removing or complementing missing information about the registered manifestations, from which a final list of cultural manifestations was generated. The register covered topics such as: space-time organization, oral expressions (stories, legend and myths), easy symbols, community practices, ethnobotany, gastronomy, weavings and handicrafts.

\subsection{Oral Expressions}

They correspond to the body of knowledge and wisdom expressed in myths, legends, tales and other forms of oral transmission that have a symbolic value for the community and are passed on from generation to generation. Among which the following stand out (Table 2): 
Table 2. Oral expressions of the Amazonian Kiwchas.

Manifestation
Legend of Kulliur and Lucero
Symbolic use: It explains the divinity of the beings that
they consider to be protective and benevolent.

Detail of the periodicity: Occasional transmission

\section{Description}

The settlers asked the god Killa to help them protect themselves from the puma and the dangers that threaten the forest, so the god gave a beautiful, young indigenous woman the opportunity to bear two children in her womb.

One day this young woman, in her last preganancy days, went to fetch water from the river to prepare chicha (purple corn drink), but a puma attacked her and killed her. The puma was only satisfied to eat the woman and ignored the two children that were in her womb, so it put them in an ashanga (basket) to eat them later. However, what the puma did not know was that the children had divine origin and as they were sent by the god Killa, that is, the Moon, so they possessed certain powers.

By the next morning, the children had already grown into strong young men who managed to escape easily from the puma. They fled with the intention of returning to punish the puma, rid the people of their fear and avenge the death of their earthly mother. Therefore, they devised a plan to build a bridge over the Napo River, with a loose centre so that the pumas that crossed it would fall into the water and drown, but the pumas realized this and chased the brothers, who were more cunning and guided them towards a cave. Dužiru (Lucero) entered first and the pumas followed him, but he was faster and left the cave blocking the back exit with a large stone, while his brother Kuyllur did the same with the entrance to the cave, in such a way that the pumas were locked and hungry inside the cave. Then at night, Killa sent a ray of light for his sons to join him in the sky and from that day on you can hear, on moonlit nights, the pumas roar hungrily from the bowels of the Napo mountain range.

\section{Legend of the Sacha Runa}

Symbolic use: It details the power of spirits and protective and spectral powers to anthropomorphic beings. Detail of the periodicity: Continuous transmission

This legend is based on a very popular belief in the Amazon rainforest and its foothills. It speaks of a being that sometimes takes the form of an old man and whose mission is to scare away hunters and people who want to destroy the forest. That is why if the intentions of those who enter the forest are not good, the Sacha Runa will do everything to scare them away and even make them sick with fever, dizziness and vomiting. Also, when some people enter without any respect they will be frightened by this mythical creature that imitates spectral sounds to chase them out of the forest.

\section{Legend of the Yaku Warmi \\ Symbolic use: It details the elements of nature and attributes spectral powers to zoo-anthropomorphic beings Detail of the periodicity: Occasional transmission}

\section{Tongue-less lizard legend}

Symbolic use: Mix of historical events typical of the area, with mythical and divine aspects to give new meanings to elements of nature

Detail of the periodicity: Transmission in the collective memory of the community, which very few members know
It refers to a woman who is usually seen on riverbanks and attracts fishermen with her cry and then drowns them. It is also said that she is capable of turning into a boa, and with her charms she attracts men to become their partners.

The lizard was one of the animals that sang the most and was also a violinist. Gifted with its beautiful voice, it made the animals be attracted to its music, so the lizard took advantage of this to to eat them. Seeing that the small animals were gradually disappearing in the forest, two brothers of mystical origin called Killiur and Lucero decided to stop the lizard and devised a plan to shut it up and stop it from eating the animals. So they decided to take a drink (liquour) to befriend the lizard and carry out their plan. Once these two brothers became friends with the lizard, they started giving it a lot to drink while it sang. After a moment of trust and a lot of alcohol, the lizard got drunk and the brothers took the opportunity to cut off its tongue so that it could no longer sing, and thus stop eating the forest animals, so it is since then that the lizard has no tongue. 
Table 2. Cont.

\begin{tabular}{|c|c|}
\hline Manifestation & Description \\
\hline $\begin{array}{l}\text { Myth of the blind snake } \\
\text { Symbolic use: It explains death with mythical aspects and } \\
\text { gives new meanings to elements of nature } \\
\text { Detail of the periodicity: Continuous transmission, } \\
\text { mainly among people who go to work in the mountains or } \\
\text { walk in the forest. }\end{array}$ & $\begin{array}{l}\text { If while walking in the mountains or forest one comes across a } \\
\text { blind snake, specifically the Amphisbaena bassleri, commonly known } \\
\text { as the blind snake or bad omen snake, it means that a person close to } \\
\text { or known to those who see the snake is going to die. }\end{array}$ \\
\hline $\begin{array}{l}\text { Guadua water myth } \\
\text { Symbolic use: It details the ethnobotanical use of the } \\
\text { elements of nature and gives new meanings to their } \\
\text { daily activities. } \\
\text { Detail of the periodicity: Continuous transmission }\end{array}$ & $\begin{array}{l}\text { It has two parts: the first part says that if you are walking in the } \\
\text { forest and you are lost, drinking guadua water will help you find } \\
\text { your way. The second part is a belief that appeals to women's vanity, } \\
\text { if they wash their hair with guadua water, it will grow healthy and } \\
\text { shiny, so that is why most women in the Amazon have long hair. }\end{array}$ \\
\hline $\begin{array}{l}\text { Illa Yura myth } \\
\text { Symbolic use: It explains death with mythical aspects and } \\
\text { gives new meanings to elements of nature } \\
\text { Detail of the periodicity: It is told every time people go } \\
\text { for a walk in the virgin forest, especially in the afternoon }\end{array}$ & $\begin{array}{l}\text { The myth of the Illa Yura or mata palo mentions that if people } \\
\text { walking through the mountains or forest come across this type of tree } \\
\text { that seems to be composed of only lianas, it is because they or } \\
\text { someone close to them is going to die, so as a countermeasure they } \\
\text { would burn the tree. Nowadays, you have to walk through virgin } \\
\text { rainforest to find this tree. }\end{array}$ \\
\hline
\end{tabular}

\subsection{Face Paints}

The Amazonian Kichwas express the elements linked to their world view, through a series of facial designs which represent elements of nature, animal skills and the energies that surround the territory (Tables 3 and 4).

Table 3. Designs of facial symbols and meanings.

Name: Reflection of the sun.
Representation: Luminous reflection of the sun, on mountains, rivers and roads
Used by: It is for the exclusive use of women in cultural events in the community
Meaning/body part where it is used/occasions for use: Women paint this design to
obtain the energy of the mountains and the luminosity of the sun. Among the Kichwas
of the Amazon, the sun controls the weather and provides light. For this reason,
women have this design on the front of their face, because a person's intelligence is
right there
Colours: Dark black/blue resulting from the Wituk fruit

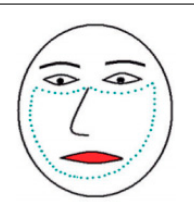

Name: The seeds.

Representation: The seeds that the woman sows in her vegetable garden, which at the same time shows the good harvest

Used by: Women

Meaning/body part where it is used/occasions for use: This design is related to the Kay Pacha and the Uku Pacha. For this reason, the figure is designed from the cheeks to the chin. It is used during marriage

Colors: Dark violet obtained from the Shiwangu muyu seed. Nowadays it is also used in a reddish/yellow colour because it is made from the seed of the achiote plant

Name: The anaconda.

Representation: Vital energy of creation.

Used by: Yachak in ceremonial and cultural events

Men and warriors

Women and pregnant women's bellies to protect their child

Meaning/body part where it is used/occasions for use: The anaconda is the link

between the Kay Pacha world and the other energy dimensions

Colours: Dark black/blue resulting from the Wituk fruit 
Table 3. Cont.

\begin{tabular}{|c|c|}
\hline Design & Characteristics \\
\hline & $\begin{array}{l}\text { Name: Lumu tarpuna } \\
\text { Representation: Sowing of yucca } \\
\text { Used by: Exclusive use by women } \\
\text { Meaning/body part where it is used/occasions for use: Protection of yucca plants. It } \\
\text { is used on the face } \\
\text { Colors: Reddish/yellow made from the seed of the achiote plant }\end{array}$ \\
\hline & $\begin{array}{l}\text { Name: The Kuraka } \\
\text { Representation: Balanced relationship between man and nature } \\
\text { Used by: Yachak Men } \\
\text { Meaning/body part where it is used/occasions for use: On walks to visit family } \\
\text { accompanied by musical instruments such as the drum, pingullo and turumpa } \\
\text { Colours: Dark black/blue resulting from the Wituk fruit }\end{array}$ \\
\hline & $\begin{array}{l}\text { Name: The rayu } \\
\text { Representation: It emphasizes the leader role that a person has when controlling a } \\
\text { group } \\
\text { Used by: Women and men } \\
\text { Meaning/body part where it is used/occasions for use: It emphasizes that whoever } \\
\text { has it painted, has a trained mind and acts efficiently } \\
\text { Colours: Dark black/blue resulting from the Wituk fruit }\end{array}$ \\
\hline $\begin{array}{r}x=x \cdot a \\
\mathbb{A}\end{array}$ & $\begin{array}{l}\text { Name: Kuyllur and Dužiru } \\
\text { Representation: Strength, power, courage and wisdom } \\
\text { Used by: Men and women } \\
\text { Meaning/body part where it is used/occasions for use: Used by warriors, hunters or, } \\
\text { in rituals and ceremonies } \\
\text { Colours: Dark black/blue resulting from the Wituk fruit }\end{array}$ \\
\hline
\end{tabular}

\begin{tabular}{|c|c|}
\hline $\boldsymbol{\Delta} \mathbf{V}$ & $\begin{array}{l}\text { Name: Amazanka } \\
\text { Representation: It is used to receive the power of knowledge } \\
\text { Used by: Children } \\
\text { Meaning/body part where it is used/occasions for use: Hiking in the forest } \\
\text { Colours: Dark black/blue resulting from the Wituk fruit }\end{array}$ \\
\hline & $\begin{array}{l}\text { Name: Owl } \\
\text { Representation: Receiving the power of the owl's knowledge-intelligence } \\
\text { Used by: Children } \\
\text { Meaning/body part where it is used/occasions for use: Hiking in the forest } \\
\text { Colours: Dark black/blue resulting from the Wituk fruit }\end{array}$ \\
\hline & $\begin{array}{l}\text { Name: Anka, ñanpi, yawati } \\
\text { Representation: Acquiring skill powers } \\
\text { Used by: Men and women } \\
\text { Meaning/body part where it is used/occasions for use: The design contains three } \\
\text { motifs: the figure of the eagle that symbolizes leadership on a woman's forehead; the } \\
\text { figure on the nose means roads or mountains which one has to cross and deal with } \\
\text { life's obstacles; the design found on the jaw symbolizes the turtle that has a long life } \\
\text { Colours: Dark black/blue resulting from the Wituk fruit }\end{array}$ \\
\hline & $\begin{array}{l}\text { Name: Charapa } \\
\text { Representation: To represent community importance aimed at problem solving } \\
\text { Used by: Exclusive use by men } \\
\text { Meaning/body part where it is used/occasions for use: The charapa (turtle) is } \\
\text { considered a patient animal and achieves a long life. Those who paint this design are } \\
\text { of strong character } \\
\text { Colours: Dark black/blue resulting from the Wituk fruit }\end{array}$ \\
\hline
\end{tabular}


Table 3. Cont.

Design Characteristics

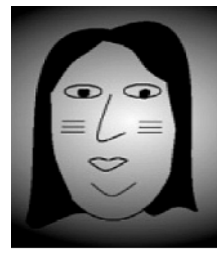

Name: Nunkulli

Representation: Female fertility

Used by: Women

Meaning/body part where it is used/occasions for use: The woman who has paju de

la siembra, paints three lines with achiote on her cheeks and one line on her chin,

representing the yucca stakes. She paints herself like this when she goes sowing. It is

used during marriage

Colours: Reddish/yellow which is made from the seed of the achiote plant

During the design process, the following materials are used:

Table 4. Materials for facial designs.

\begin{tabular}{ll}
\hline Kichwa & Materials \\
\hline Inayu & Splinter of a palm species \\
\hline Wamak tullu & Guadua Splinter \\
\hline Kallana & Earthenware plate \\
\hline Shiwa panka tullu & Unguragua Leaf Splinter \\
\hline Chili panka tullu & Fibre sheet splinter \\
\hline Wituk muyu & Fruit of Wituk \\
\hline Pilchi & Pilchi bowel \\
\hline Shikita & Natural grater \\
\hline Cuchillo & Knife \\
\hline Sacha muyukuna & Wild fruits \\
\hline Chunta kaspi & Chonta splinter \\
\hline Nina & Candle \\
\hline Putu & Cotton \\
\hline Yaku & Water \\
\hline Panka & Leaves \\
\hline
\end{tabular}

\subsection{Traditional Craft Techniques}

It refers to the processes, skills, knowledge, techniques and symbolic uses that intervene in the process of making fabrics, which are full of cultural value and contribute to the development of daily activities (Table 5).

\subsection{Guayusa-Ethnobotany}

Waysa, whose scientific name is Ilex guayusa and belongs to the Aquifoliaceae family, is a plant commonly used by the nine nationalities of the Amazon. This plant has a number of medicinal uses through the consumption of water from its leaves (Table 6), which range from being an energizing drink to relieving general body ailments. In addition to this, in the ancestral vision it enables hunters to acquire forest skills, but at the same time, it neutralizes the bad omens that they may acquire during their day, for which they bath in the boiled water from this plant's leaves, which restores balance with nature [43].

Guayusa provides a different energy to that provided by coffee or any other type of caffeinated tea. It is considered an ancient plant, which is why it is classified as a sacred plant. The consumption of its drink constitutes one of the most important rituals for many Amazonian peoples, especially for the Amazonian Kichwa [44], since they have their own ceremony with this plant, which is the Guayusaupina. 
Table 5. Handicraft techniques of the Amazonian Kiwchas.

\begin{tabular}{ll}
\hline \multicolumn{1}{c}{ Manifestation } & \multicolumn{1}{c}{ Description } \\
\hline Lisan ashanga fabric & $\begin{array}{l}\text { The ashanga is a basket generally made of fibre which is extracted from the } \\
\text { stalk of the toquilla straw, commonly known in the area as lisan. The } \\
\text { weaving starts at the base and goes up in crosses in such a way that } \\
\text { diamonds are formed. At the end, the remaining edges of the fibres are } \\
\text { knotted between the diamonds. If desired, a strap is braided and tied } \\
\text { around the edges to form a bag. Ashangas are used to transport products } \\
\text { or to store things. } \\
\text { Material: Toquilla straw }\end{array}$
\end{tabular}

Shikra fabric

The shikra is useful for carrying things. It is woven in different sizes according to people's convenience, as it is used for different activities, such as carrying personal belongings when hunting, carrying food or field tools. Material: Pita tree fibre

Making the clay pot

The clay pot is an artifact that is used in the community for different purposes, such as: cooking, fermenting chicha and storing food. The vessel has a rounded and flattened base to stand upright, a circular mouth, a circular neck, is orange in colour and has no engravings on it.

Material: Made only from clay and the modelling technique is used

Lika fabric

The lika is a tool used by the community people for fishing. It is a net made of synthetic material, which is made when fishing, although unlike other tools made from other materials, this one has a longer lifespan. It is circular in shape and is woven loosely in a rhomboid shape. To use it, the open net is cast into a body of water in which you want to fish, and then immediately pulled up by pulling on a rope tied in the middle of the net. If any fish have been caught, they are removed from the net and it is kept for use on another occasion. Material: Nylon

Wami fabric

Wami is a tool that the community people use for fishing. It is made every time they go fishing, for which the bark of the toquilla straw is cut into long, thin strips. It has a conical shape and is woven without much separation from the tip to the base, it has the shape of a round mouth. For its use, the open and rounded part is placed in the opposite direction to the current of a stream so that the fish can enter the stream to the bottom and, due to the water, cannot get out of it until a person comes back to check if they have managed to catch something. Material: Toquilla straw

Crafts such as necklaces, bracelets, cuffs, traditional costumes and instruments

The elaboration of this seed jewellery is used and made throughout the Amazon region by the different existing nationalities and peoples. Material: Calmito, Ishpa muyu, Anamora, Pishkuma and Achira muyu seeds are used for jewellery. The Pingullo stem is used for flutes. For clothing, the leaves of Piton, Marpindu and Killu sisa are used.

Table 6. Guayusa and its relationship with energy.

\begin{tabular}{lll}
\hline \multicolumn{1}{c}{ Type of Energy } & \multicolumn{1}{c}{ Obtained } & \multicolumn{1}{c}{ Use } \\
\hline Physical energy & Through the intake of Guayusa & $\begin{array}{l}\text { The energy obtained from the } \\
\text { Guayusa is released through activities } \\
\text { that cause physical exhaustion }\end{array}$ \\
\hline Spiritual energy & $\begin{array}{l}\text { Guayusa as a symbol that } \\
\text { provides good energy }\end{array}$ & Clean \\
\hline Mental energy & Guayusa as a relaxation tool & $\begin{array}{l}\text { Guayusa essences and oils } \\
\text { for relaxation }\end{array}$ \\
\hline
\end{tabular}

The Guayusaupina is a ceremony that takes place in the indigenous Kichwa communities of the Amazon. It is carried out in order to revitalize the ancestral values of the people, allowing people to share their experiences, customs and traditions, in addition 
to interpreting dreams, to make decisions that are important in their lives. During the ritual, Guayusa and yuca chicha are constantly drunk. Finally, the food is shared with everyone present.

This plant is characterized by having first of all, natural caffeine, which is released gradually into the bloodstream, a feature which reduces the possibility of producing a nervous breakdown or sudden caffeine shock as produced with other caffeinated or energizing drinks [45] (Tables 6 and 7).

Table 7. Uses of guayusa.

\begin{tabular}{|c|c|c|}
\hline Type of Use & Body Part/Product & Description \\
\hline \multirow{6}{*}{ Medicinal } & Central Nervous System & $\begin{array}{l}\text { It increases extracellular levels of the neurotransmitters } \\
\text { norepinephrine and dopamine, which help the person ingesting } \\
\text { it to achieve good concentration and attention. It also reduces } \\
\text { sleepiness and tiredness, increasing the body's energy }\end{array}$ \\
\hline & Cardiovascular system & $\begin{array}{l}\text { It develops a positive inotropic effect and increases cardiac } \\
\text { output and is therefore used therapeutically as a cardiotonic, } \\
\text { diuretic and nerve centre stimulant. }\end{array}$ \\
\hline & Skeletal muscles & $\begin{array}{l}\text { It increases performance in relation to endurance and } \\
\text { exercise capacity }\end{array}$ \\
\hline & Respiratory system & It is a bronchodilator in respiratory diseases \\
\hline & Digestive system & $\begin{array}{l}\text { It reduces the risk of colorectal and colon cancer, as well as } \\
\text { symptoms and development of gallstones. It also serves as } \\
\text { a purgative }\end{array}$ \\
\hline & Endocrine glands & $\begin{array}{l}\text { It increases insulin sensitivity and reduces the risk of diabetes, } \\
\text { due to its antioxidant properties }\end{array}$ \\
\hline \multirow{3}{*}{ Cosmetic } & Anti-cellulite & It prevents excessive fat accumulation in cells \\
\hline & Solar filter & $\begin{array}{l}\text { Antioxidant properties that help protect skin cells against UV } \\
\text { radiation and delays aging }\end{array}$ \\
\hline & Alopecia & It stimulates hair growth. \\
\hline
\end{tabular}

\section{Conclusions}

Ecuador is defined as a plurinational country within which 14 nationalities and 18 indigenous, Afro-Ecuadorian and Montubio peoples coexist. Based on this, the principle of interculturality for the development of human groups in the territory is established and recognized. Taking this into account, the appreciation and safeguarding of the Intangible Cultural Heritage (ICH) is promoted. ICH has been referred to as the "poor relative" of culture or "minor heritage", as it has been constantly neglected, highlighting more work to create norms and preserve the tangible cultural heritage, which is more "representative" for the country's public sector.

Based on this, it has been identified that the safeguard processes of the "living heritage" within the rural areas of the Amazon are incipient. The situation of the ICH is increasingly critical due to the fact that a large percentage of the manifestations are in a highly vulnerable state of sensitivity to change. Although the Kichwas, like the rest of the peoples of the Ecuadorian territory, are in a process of social insurgency, the transmission processes are less and less effective, aggravated by the globalization of spaces and by the lack of respect for ancestral territories with concessions for the extraction of resources. The Amazonian Kichwa nationality maintains revitalization processes within its communities, encouraging the safeguarding of their heritage, but above all, the strengthening of the identity of their members as Runas.

The purpose of this research was to document the indigenous knowledge of the Kichwas people, as part of their heritage and cultural identity, in order to preserve traditional knowledge more durably than just its oral propagation. For this, an inventory of its intangible cultural heritage was carried out as a tool to safeguard this heritage. This 
inventory is intended to serve as a tool to sensitize society to the importance of the heritage of the Kichwas people, as well as to improve the self-esteem of this people with respect to their cultural wealth. On the other hand, this inventory can serve as the basis for formulating concrete plans for the intangible cultural heritage of this indigenous people. In this sense, once the specific elements of the heritage have been identified, it facilitates the implementation of pilot projects for their safeguarding and revitalization. Among them the development of tourism supported by this intangible cultural heritage.

There are several measures to safeguard popular and traditional culture that can be carried out in addition to the preparation of this inventory. These measures are included in the Methodological Guide for the safeguarding of the Intangible Cultural Heritage [5] prepared by Ecuador, such as the creation of national archives, the implementation of school programs, the creation of government agencies, the promotion of research and dissemination and protection measures focused on intellectual property rights. Measures that are currently in an incipient process. All these actions have the main objective of strengthening the identity of the groups, communities and carriers involved and, based on this, the safeguarding aims at the generation of local capacities that allow strengthening local development processes [5] (p. 35). Tourism is configured as a privileged area to carry out measures to safeguard the intangible cultural heritage and therefore helps local and regional development.

It is necessary to mention that the safeguarding and transmission of intangible cultural heritage essentially rests on the will and effective intervention of those who are linked to it; makers, carriers of knowledge and knowledge, of groups and communities, governmental and non-governmental institutions, academia and the general public [5] (p. 38). In the case of Ecuador, the safeguarding of cultural heritage is a duty of the state included in the Constitution: for this, the National Institute of Cultural Heritage is in charge of developing specific measures for its management: legal framework (National Constitution, international instruments, national Laws, Decrees, regulations, instructions [5] (p. 37). To guarantee the continuity of this process, governments have the duty to adopt measures that promote the democratic participation of all interested agents". [5] (p. 13).

Finally, in the Methodological Guide for the safeguarding of the Intangible Cultural Heritage [5] it states that "regardless of its official recognition, the Intangible Cultural Heritage exists as long as the conditions for the production and transmission of knowledge by the host communities exist. For this reason, priority was given to the definition of procedures and instruments that allow the safeguarding of the ICH. These include: identification, investigation, and safeguarding plans. [5] (p. 17).

Author Contributions: Conceptualization, C.P.M.-E., N.P.T.-T., M.d.l.C.d.R.-R. and J.Á.-G.; Formal analysis, C.P.M.-E., N.P.T.-T., M.d.l.C.d.R.-R. and J.Á.-G.; Investigation, C.P.M.-E., N.P.T.-T., M.d.l.C.d.R.-R. and J.Á.-G.; Methodology, C.P.M.-E., N.P.T.-T., M.d.l.C.d.R.-R. and J.Á.-G.; Writingoriginal draft, C.P.M.-E., N.P.T.-T., M.d.l.C.d.R.-R. and J.Á.-G.; Writing-review \& editing, C.P.M.-E., N.P.T.-T., M.d.l.C.d.R.-R. and J.Á.-G. All authors have read and agreed to the published version of the manuscript.

Funding: This research received no external funding.

Institutional Review Board Statement: Not applicable.

Acknowledgments: The authors thank the Plurinational Federation of Community Tourism of Ecuador (FEPTCE) and the Parish GAD of Puerto Napo for their willingness and support in the revitalization processes with the communities under study.

Conflicts of Interest: The authors declare no conflict of interest.

\section{References}

1. Leal González, N. Patrimonio cultural indígena y su reconocimiento institucional. Opción 2008, 24, $28-43$.

2. Williams, V.I. Patrimonio Nacional. Poblaciones Indigenas y Patrimonio Intangible. Nuevo Mundo Mundos Nuevos. Nouveaux Mondes Mondes Nouveaux-Novo Mundo Mundos Novos-New World New Worlds. 2013. Available online: https: / /journals. openedition.org/nuevomundo/65998 (accessed on 23 October 2021). 
3. UNESCO. Declaración de México sobre las políticas culturales. In Conferencia Mundial Sobre las Politicas Culturales; United Educational, Scientific and Cultural Organization (UNESCO): Paris, France, 1982.

4. UNESCO. Convención para la Salvaguardia del Patrimonio Cultural Inmaterial. 2003. Available online: http:/ /www.unesco.org/ culture/ich/index.php?pg=00022 (accessed on 23 October 2021).

5. Cultural, I.N. Guia Metodologica para la Salvaguardia del Patrimonio Cultural Inmaterial. Quito: Con Clave Esudio. 2013. Available online: https://issuu.com/inpc/docs/salvaguardiainmaterial (accessed on 23 October 2021).

6. UNESCO. Living Heritage and Indigenous Peoples. The Convention for the Safeguarding of the Intangible Cultural Geritage; United Educational, Scientific and Cultural Organization (UNESCO): Paris, France, 2019.

7. United Nations. Declaración de Naciones Unidas sobre los Derechos de los Pueblos Indígenas. 2007. Available online: https:/ / www.un.org/esa/socdev/unpfii/documents/DRIPS_es.pdf (accessed on 23 October 2021).

8. UNESCO. Identifying and Inventorying Intangible Cultural Heritage. Available online: https://ich.unesco.org/doc/src/01856ES.pdf (accessed on 23 October 2021).

9. Andy Alvarado, P.; Calapucha Andy, C.; Calapucha Cerda, L.; López Shiguango, H.; Tanguila Andy, A.; Tanguila Andy, D. Historia Kichwa Amazónca. In Sabiduría de La Cultura Kichwa de La Amazonía Ecuatoriana. Tomo II; Universidad de Cuenca, UNICEF, DINEIB, Eds.; MEGASOFT: Chennai, India, 2012; pp. 117-129. Available online: https:/ / www.educacionbilingue.gob. ec/wp-content/uploads/2019/12/1-Sabiduria-de-la-Cultura-Kichwa-T2_compressed.pdf (accessed on 4 May 2021).

10. Vizcaíno, V.A. Chakras, Bosques y Ríos: El Entramado de La Biocultura Amazónica; INIAP Archivo Historico: Quito, Ecuador, 2009.

11. Restrepo, M.; Cabrejas, A. Canelos: Cuna de Pastaza; Casa de la Cultura Ecuatoriana Benjamín Carrión: Quito, Ecuador, 1998.

12. De Cultura, M. Indigenous or Native Peoples Database: Kichwas Published; Ministerio de Cultura: Quito, Ecuador, 2020. Available online: https:// bdpi.cultura.gob.pe/pueblos/kichwa (accessed on 8 September 2021).

13. HELVETAS Swiss Intercooperation, Rights and Resources Initiative. Territorio Indígena y Gobernanza: Kichwas de Napo/Indigenous Territory and Governance: Kichwas de Napo. 2020. Available online: https:/ / www.territorioindigenaygobernanza.com/web/ necu_13/ (accessed on 5 May 2021).

14. Castro, N.C.; Tapuy, A.M.G. La Música Kichwa en la Práctica de Danzas Ancestrales de los Estudiantes de la Escuela de Educación Básica Tarqui de la Comunidad Tambayacu, Cantón Archidona, Provincia de Napo, año 2014-2015; Universidad Tecnológica de IdoAmérica: Ambato, Ecuador, 2017. Available online: http:/ / repositorio.uti.edu.ec/handle/123456789/414 (accessed on 5 May 2021).

15. Toscano, S.A.S. Analysis of the Approach of the Territorial Circumscription of the Kichwa Nationality of the Province of Pastaza (2008-2010); Universidad Politécnica Salesiana: Quito, Ecuador, 2011. Available online: http://bibliotecavirtualoducal.uc.cl:8081/handle/12 $3456789 / 1443893$ (accessed on 5 May 2021).

16. HELVETAS Swiss Intercooperation, Rights and Resources Initiative. Kichwas de Pastaza: The Construction of an Autonomous Government Proposal. 2020. Available online: https://www.territorioindigenaygobernanza.com/web/ecu_14/(accessed on 5 May 2021).

17. Ayala, E. Historia Del Ecuador I: Época Aborigen y Colonial, Independencia; Universidad Andina Simón Bolívar/Corporación Editora Nacional: Quito, Ecuador, 2015.

18. Albán, A. Sistema Médico Indígena entre los Kichwas Amazónicos: Prácticas Tradicionales e Interculturalidad. Ph.D. Thesis, Escuela Superior Politécnica de Chimborazo, Quito, Ecuador, 2015. Available online: http://repositorio.puce.edu.ec/handle/22 000/9845 (accessed on 5 May 2021).

19. Hortegón, D.; de Ortiguera, T.; Fernández Ruiz de Castro, P.; de Lemos, C. La Gobernación de Los Quijos (1559-1621); IIAP-CETA: Quito, Ecuador, 1989.

20. Garcés, A. Colonial Oppression and Indigenous Resistance. In La Alta Amazonía/ The Upper Amazon; Granero, F.S., Ed.; Abya-Yala (Universidad Politécnica Salesiana): Quito, Ecuador, 1992.

21. Oberem, U. Los Quijos: History of the Transculturation of an Indigenous Group in the Ecuadorian East; Editorial “Gallocapitán": Quito, Ecuador, 1980.

22. Rumazo, J. The Amazon Region of Ecuador in the Sixteenth Century; Escuela de Estudios Hispano Americanos de Sevilla: Seville, Spain, 1946.

23. Muratorio, B. Rucuyaya Alonso and The Social and Economic History of Alto Napo 1850-1950; Abya-Yala (Universidad Politécnica Salesiana): Quito, Ecuador, 1998.

24. Uribe Taborda, S.F.; González Serna, A.; Tôrres Aguia, E. The government of Los Quijos, Sumaco and La Canela. Frameworks of the socio-historical production process of the territory in the Upper Ecuadorian Amazon, 16th-19th centuries. Univ. Rev. Cienc. Soc. Hum. 2020, 55-76.

25. Padilla, W. La Iglesia y Los Dioses Modernos: Historia Del Protestantismo En El Ecuador; Corporación Editora Nacional: Quito, Ecuador, 2008.

26. Phelan, J.L. The Kingdom of Quito in the 17th Century; Ediciones del Banco Central del Ecuador: Quito, Ecuador, 1995.

27. Garcés, L.F. Sources for the study of the Kichwa language and its evangelizing role in Ecuador. An overview. Procesos Rev. Ecuat. Hist. 2018, 151-175.

28. Magnoni, D. Análisis etnohistórico de las resistencias y transformaciones de los Napo Runa. TRIM Tordesillas Rev. Investig. Multidiscip. 2018, 89-106.

29. Whitten, N. Amazonian Ecuador: An Ethnic Interface in Ecological, Social and Ideological Perspectives. Iwgia. Doc. Kbh. 1978, 34, 5-80. 
30. Food and Agriculture Organization of the United Nations. Biodiversity and Health in the Indigenous Populations of the Amazon; Amazon Cooperation Treaty: Brasília, Brazil, 1995. Available online: https://agris.fao.org/agris-search/search.do?recordID=PE1 995101456 (accessed on 5 May 2021).

31. De la Rosa, F.J.U. La era del caucho en el Amazonas (1870-1920): Modelos de explotación y relaciones sociales de producción. In Anales del Museo de América (No. 12); Subdirección General de Documentación y Publicaciones: Madrid, Spain, 2004; pp. 183-204

32. Mongua-Calderón, C. Caucho, frontera, indígenas e historia regional: Un análisis historiográfico de la época del caucho en el Putumayo-Aguarico. Boletín Antropol. 2018, 33, 15-34. [CrossRef]

33. Instituto Otavaleño de Antropología. Ley sobre División Territorial; Instituto Otalvaleño de Antropología-Centro Regional de Investigación: Quito, Ecuador, 1994; Available online: https://repositorio.flacsoandes.edu.ec/bitstream/10469/5412/4 /RFLACSO-Sa19.pdf (accessed on 5 May 2021).

34. Gutiérrez-Marín, W. Los misioneros josefinos, su relación con los indígenas y la conformación de la región amazónica. In Misiones, Pueblos Indígenas y La Conformación de La Región Amazónica: Actores, Tensiones y Debates Actuales; Juncosa, J., Garzon, B., Eds.; Abya-Yala (Universidad Politécnica Salesiana): Quito, Ecuador, 2019.

35. Vicuña Cabrera, A. Proceso Socio-Económico sobre la Explotación del Caucho en la Amazonía Ecuatoriana 1850-1920. 1993. Available online: http:/ / repositorio.flacsoandes.edu.ec/handle/10469/285 (accessed on 5 May 2021).

36. Instituto Geográfico Militar. Atlas Nacional Del Ecuador; Instituto Geográfico Militar-IGM: Quito, Ecuador, 2010. Available online: http:/ / dspace.ucuenca.edu.ec/handle/123456789/5504?locale=es (accessed on 5 May 2021).

37. Jarrín, P.S.; Carrillo, L.T.; Acosta, G.Z. The internal colony as a current issue: Transformation of the human territory in the Amazonian region of Ecuador. Let. Verdes Rev. Latinoam. Estud. Socioambientales 2016, 20, $22-43$.

38. Kroeger, A.; Barbira-Freedman, F. La Lucha por la Salud en el Alto Amazonas y en los Andes. Centro de Medicina Andina; Abya-Yala (Universidad Politécnica Salesiana): Quito, Ecuador, 1992. Available online: https://rraae.cedia.edu.ec/Record/UPS_6780ae7a2 cb24eddad6dac29273c0b6b (accessed on 5 May 2021).

39. Andy Alvarado, P.; Calapucha Andy, C.; Calapucha Cerda, L.; López Shiguango, H.; Tanguila Andy, A.; Tanguila Andy, D. Samay: La fuerza vital. In Sabiduría de La Cultura Kichwa de La Amazonía Ecuatoriana. Tomo II; Universidad de Cuenca, UNICEF, DINEIB, Eds.; MEGASOFT: Chennai, India, 2012; pp. 117-129. Available online: https:/ / www.educacionbilingue.gob.ec/wp-content/ uploads/2019/12/1-Sabiduria-de-la-Cultura-Kichwa-T2_compressed.pdf (accessed on 5 May 2021).

40. Andy Alvarado, P.; Calapucha Andy, C.; Calapucha Cerda, L.; López Shiguango, H.; Tanguila Andy, A.; Tanguila Andy, D. La relación armónica entre los seres humanos y las plantas. In Sabiduría de La Cultura Kichwa de La Amazonía Ecuatoriana. Tomo II; Universidad de Cuenca, UNICEF, DINEIB, Eds.; EGASOFT: Grosseto, Italy, 2012; pp. 225-234. Available online: https://www. educacionbilingue.gob.ec/wp-content/uploads/2019/12/1-Sabiduria-de-la-Cultura-Kichwa-T2_compressed.pdf (accessed on 5 May 2021).

41. ILO Convention. Convenio No. 169 de La OIT. 1989. Available online: https://www.ilo.org/wcmsp5/groups/public/--americas/---ro-lima/documents/publication/wcms_445528.pdf (accessed on 5 May 2021).

42. Nagoya Protocol. Convenio sobre la Diversidad Biológica Naciones Unidas. Protocolo de Nagoya. 2011. Available online: https:/ / www.cbd.int/abs/doc/protocol/nagoya-protocol-es.pdf (accessed on 5 May 2021).

43. Ecuadorian Code of Ingenuity. 2016. Available online: https://www.asle.ec/wp-content/uploads/2016/12/ingenios-09-12-2016 .pdf (accessed on 5 May 2021).

44. Dueñas, J.F.; Jarrett, C.; Cummins, I.; Logan-Hines, E. Amazonian Guayusa (Ilex guayusa Loes.): A historical and ethnobotanical overview. Econ. Bot. 2016, 70, 85-91. [CrossRef]

45. Alvarez, R.D.M. Factibilidad para la Creación de una Empresa Comercializadora de la Bebida Energizante a Base de Guayusa "Runa" en el Mercado de Guayaquil. Ph.D. Thesis, Universidad Técnica Particular de Loja, Loja, Ecuador, 2014. Available online: http:/ / repositorio.ucsg.edu.ec/handle/3317/2227 (accessed on 5 May 2021). 